\title{
Faktor-Faktor yang Mempengaruhi Produksi Usahatani Terong Ungu di Kelompok Tani Koko Naibate Desa Manunain A Kecamatan Insana
}

\author{
Jefrianus Tanik ${ }^{\mathrm{a}}$ \\ ${ }^{a}$ Fakultas Pertanian, Universitas Timor, Kefamenanu, TTU - NTT, Indonesia.
}

\section{Article Info}

\section{Article history:}

Received 9 April 2018

Received in revised form 30 Juni 2018 Accepted 26 Juli 2018

\section{DOI:}

https://doi.org/10.32938/ag.v3i3.283

Keywords:

Faktor Produksi

Terong Ungu

Manunain A

\section{Pendahuluan}

Indonesia adalah Negara agraris yang sebagian besar penduduknya terdiri dari petani, sehingga sektor pertanian memegang peranan penting. Sektor pertanian sebagai sumber kehidupan bagi sebagian besar penduduk terutama bagi mereka yang memiliki mata pencaharian utama sebagai petani. Selain itu sektor pertanian, salah satu hal penting yang harus diperhatikan sebagai penyedia pangan bagi masyarakat. Peningkatan produksi yang harus seimbang dengan laju pertumbuhan penduduk dapat dicapai melalui peningkatan pengelolaan usahatani secara intensif (Tou, 2017)

Pertanian dapat digolongkan atas beberapa sektor antara lain sub sektor perkebunan, peternakan, kehutanan dan sub sektor tanaman pangan. Sub sektor tanaman pangan merupakan salah satu sektor yang banyak dikembangkan. Pengembangan sub sektor tanaman pangan dapat digolongkan atas beberapa jenis tanaman yaitu tanaman padi, palawija, tanaman hortikultura (sayur-sayuran) dan tanaman buah-buahan (Phahlevi, 2013).

Proses produksi bisa berjalan bila persyaratan faktor produksi yang dibutuhkan sudah terpenuhi. Faktor produksi terdiri dari empat komponen, yaitu tanah, modal, tenaga kerja, dan skill atau manajemen (pengelolaan). Dalam beberapa literatur, sebagian para ahli mencantumkan hanya tiga faktor produksi, yaitu tanah, modal, dan tenaga kerja. Masing-masing faktor mempunyai fungsi yang berbeda dan saling terkait satu sama lain. Jika salah satu faktor tidak tersedia maka proses produksi atau usahatani tidak akan berjalan, terutama ketiga faktor seperti tanah, modal dan tenaga kerja (Murdiantoro, 2011)

Terong ungu (Solanum melongena L.) merupakan jenis tanaman sayursayuran yang dikonsumsi dalam bentuk lalap (sayuran segar) atau direbus, gulai, sambal dan lain sebagainya. Tanaman terong banyak digemari karena selain rasanya enak dan harganya relatif murah, kandungan gizinya pun cukup lengkap yaitu protein, lemak, karbohidrat, vitamin A, vitamin B, vitamin C, Fosfor, dan zat besi. Terong mempunyai nilai ekonomis yang cukup tinggi dan telah mampu menerobos pasaran (Rukmana, 2007).

Kecamatan Insana di Kabupaten Timor Tengah Utara (TTU) merupakan salah satu kecamatan yang memiliki lahan pertanian yang luas dan potensial untuk berusahatani terong. Berdasarkan data yang diperoleh dari Kecamatan Insana dalam (empat) tahun terakhir yaitu tahun 2012 luas panen 3,061 ha dengan produksi sebesar 2 ton, tahun 2013 luas panen 2,246 ha dengan produksi sebesar 1,8 ton, tahun 2014 luas panen 1,632 ha dengan produksi sebesar 1,5 ton dan tahun 2015 luas panen 3,357 ha dengan produksi sebesar 2,5 ton

Kelompok tani Koko Naibate merupakan salah satu dari 85 kelompok tani yang berada diwilayah Kecamatan Insana dan mempunyai lahan pertanianproduktif untuk mengembangkan usahatani terong ungu. Usahatani terong ungu di kelompok tani Koko Naibate desa Manunain A dengan luas lahan keseluruhan 120 are atau 1,2 ha dengan produksi pada tahun 2012 sebesar 1,5 ton, tahun 2013 1,3 ton, tahun 20141 ton, dan tahun 20151,4 ton. Berdasarkan data yang diperoleh pada saat pengambilan data awal, kelompok tani Koko Naibate Desa Manunain A biasanya menjual terong ungu di pasar-pasar terdekat. Terong ungu juga dijual untuk memenuhi kebutuhan keluarga, biaya anak sekolah dan urusan sosial. Produksi yang berfluktuasi membuat pendapatan yang diterima petani sulit diprediksi oleh sebab itu perlu dilakukan kajian dengan topik faktor-faktor yang mempengaruhi produksi usahatani terong ungu di kelompok tani Koko Naibate Desa Manunain A Kecamatan Insana. Penelitian ini bertujuan untuk mengetahui 1) gambaran umum usahatani terong ungu; dan faktor-faktor yang mempengaruhi produksi usahatani terong ungu di Kelompok Tani Koko Naibate Desa Manunain A

\section{Metode}

Penelitian dilaksanakan di kelompok tani Koko Naibate Desa Manunain A Kecamatan Insana Kabupaten TTU. Waktu pelaksanaan terhitung mula dari bulan Juni sampai dengan bulan September 2017. Metode yang digunakan dalam pengambilan data adalah metode wawancara langsung dengan petani sampel dan berpedoman pada daftar pertanyaan yang ada pada kuesioner yang telah disiapkan terlebih dahulu. Metode pencatatan yaitu teknik pengumpulan data dengan cara mencatat jawaban petani atas pertanyaan yang diajukan di luar dari daftar pertanyaan yang ada pada kuesioner.

Populasi dalam penelitian ini adalah seluruh petani yang berusahatan terong ungu di Kelompok tani Koko Naibate Desa Manunain A Kecamatan Insana, sampel dalam penelitian ini diambil dengan metode sensus (sampel jenuh) dimana semua petani terong ungu (25 orang) dijadikan sebagai sampel dalam penelitian ini.

Untuk mengetahui tujuan pertama digunakan metode analisis deskriptif kualitatif sesuai petunjuk Sugiyono, (2006), sedangkan untuk mengetahui tujuan kedua digunakan model analisis Cobb-Douglas sesuai petunjuk Soekartawi, (1990). Secara matematis fungsi Cobb-Douglas dalam penelitian ini dituliskan $\mathrm{Y}=\mathrm{AX}_{1}^{\mathrm{b} 1} \mathrm{X}_{2}^{\mathrm{b} 2}, \ldots \ldots, \mathrm{X}_{\mathrm{i}}^{\mathrm{bi}}, \ldots \mathrm{X}_{\mathrm{n}}^{\mathrm{bn}} \mathrm{e}^{\mathrm{u}}$. Fungsi CobbDouglas tersebut dinyatakan oleh hubungan $\mathrm{Y}$ dan $\mathrm{X}$ yakni $\quad \mathrm{Y}=\mathrm{f}$ $\left(\left(\mathrm{X}_{1}, \mathrm{X}_{2}, \mathrm{X}_{3}, \mathrm{X}_{4}, \mathrm{X}_{5}, \mathrm{X}_{6}\right)\right.$ dimana:
$\mathrm{Y} \quad$ : Jumlah produksi terong $(\mathrm{kg})$
$\mathrm{X}_{1} \quad$ : Luas lahan (are)
$\mathrm{X}_{2} \quad$ : Benih (gram)
$\mathrm{X}_{3} \quad$ Tenaga Kerja $(\mathrm{HKO})$
$\mathrm{X}_{4} \quad$ : Pengalaman Usahatani (Tahun)
$\mathrm{X}_{5} \quad$ : Tingkat Pendidikan
$\mathrm{X}_{6} \quad$ : Tanggungan Keluarga (orang)
$\mathrm{A}, \mathrm{b}$ : besaran yang akan diduga
$\mathrm{U}_{1} \quad$ : Kesalahan Pengganggu (disturbance term)
$\mathrm{b}_{\mathrm{o}} \quad$ : intersep
$\mathrm{b}^{1} \quad$ : koefisien regresi faktor produksi ke $-\mathrm{i}(\mathrm{i}=1,2,3,4,5)$
: logaritma natural $(2,7182)$

Untuk memudahkan pendugaan terhadap persamaan di atas maka persamaan tersebut diubah menjadi bentuk linear berganda dengan cara melogaritmakan persamaan tersebut yang dituliskan $\operatorname{Ln} Y=\operatorname{Ln} a+b_{1} \operatorname{Ln} X$ $+b_{2} \operatorname{Ln} X_{2}+\ldots .+b_{n} \operatorname{Ln} X_{n}+e i$. Analisis data dilakukan menggunakan bantuan aplikasi SPSS.16 yang dilakukan sesuai petunjuk Santoso, (2008).

\section{Hasil dan Pembahasan}

\subsection{Deskripsi Usahatani Terong Ungu}

Usahatani terong ungu di lokasi penelitian memiliki luas lahan yang berbeda-beda berkisar antara $15-25$ are. Budidaya terong ungu yang dilakukan oleh kelompok tani Koko Naibate biasanya dilakukan pada bulan Juni dan jenis yang dibudidayakan adalah jenis terong ungu varietas Laguna F1. Pola tanam pada kelompok tani Koko Naibate menggunakan sistem tumpang sari atau selain terong ungu ada juga tanaman lain seperti kangkung, sawi, tomat dan lombok. Usahatani yang dilakukan di lokas penelitian antara lain persiapan dan pengolahan lahan, pemilihan benih, persemaian, penanaman, pemeliharaan, panen dan pasca panen.

a. Persiapan dan Pengolahan Lahan

Lahan yang digunakan untuk budidaya tanaman terong ungu harus dibersihkan terlebih dahulu. Rumput dibersihkan menggunakan parang atau tajak dan persiapan lahan dilakukan pada bulan Juni. Waktu yang digunakan responden untuk mempersiapkan lahan 7-10 hari. Tanah dicangkul atau dibajak dengan menggunakan pacul atau traktor dengan tujuan untuk menggemburkan tanah sehingga tanaman terong ungu tumbuh dengan baik Setelah itu dibuat dalam bentuk lubang dengan diameter $20 \mathrm{~cm}$ dan jarak antara lubang yang satu dengan lubang yang lainnya $40-50 \mathrm{~cm}$. Kelompok 
tani Koko Naibate menggunakan tenaga kerja dalam keluarga yang berjumlah 28 orang dengan rerata curahan tenaga kerja sebesar 17,74 HKO. b. Pemilihan Benih

Benih terong ungu didapat dari toko pertanian terdekat. Benih yang digunakan di kelompok tani Koko Naibate adalah benih varietas Laguna F1. Pemilihan benih yang dilakukan di kelompok tani Koko Naibate yang didapat dari toko yaitu benih tersebut di sebarkan ke bedeng yang telah disiapkan. Kelompok tani Koko Naibate menggunakan tenaga kerja dalam keluarga yang berjumlah 32 orang dengan rerata curahan tenaga kerja sebesar $10,98 \mathrm{HKO}$

c. Persemaian

Persemaian merupakan kegiatan untuk menghasilkan bibit. Benih terong ungu disemaikan dalam bedeng yang sudah dicampur dengan pupuk kandang, dan cara persemaiannya ditabur merata ke dalam bedeng manual yaitu dengan menggunakan tangan setelah itu disiram dengan air menggunakan ember agar tanah tetap lembab dan basah. Adapun bibit yang telah dapat dipindahkan menuju lubang adalah bibit yang sudah mempunyai 4-5 lembar daun. Kelompok tani Koko Naibate menggunakan tenaga kerja dalam keluarga yang berjumlah 35 orang dengan rerata curahan tenaga kerja sebesar 10,70 HKO

d. Penanaman.

Penanaman dilakukan setelah bibit berumur 17 - 27 hari dengan kriteria 4 - 5 helai daun dan memiliki akar dan batang yang kuat. Bibit terong ungu yang disemaikan dicabut secara manual dan ditanam pada lubang berdiameter $20 \mathrm{~cm}$ yang sudah disiapkan. Tahapan Penanaman dilakukan pada pagi/sore hari dengan jarak tanam $40-50 \mathrm{~cm}$. Setelah proses penanaman selesai maka selanjutnya perlu dilakukan pemeliharaan yang baik. Kelompok tani Koko Naibate menggunakan tenaga kerja dalam keluarga yang berjumlah 42 orang dengan rerata curahan tenaga kerja sebesar $7 \mathrm{HKO}$

e. Pemeliharaan

○ Pemupukan

Pupuk yang digunakan di kelompok tani Koko Naibate adalah pupuk kandang, pupuk Urea dan TSP. Pemupukan dasar menggunakan pupuk kandang yang diberikan pada saat pengolahan tanah, yaitu ditaburkan ke dalam lubang tanam. Pemupukan kedua dilakukan setelah tanaman terong ungu berumur 2 minggu dengan pemberian pupuk Urea dan TSP dengan dosis 5 - 10 gram/pohon dengan cara dilarutkan dalam air kemudian disiram per pohon menggunakan ember. Waktu pemupukan dilakukan pada pagi atau sore hari. Rata-rata pupuk Urea yang digunakan sebanyak $4 \mathrm{~kg}$, sedangkan rata-rata pupuk TSP sebanyak $5 \mathrm{~kg}$. Kelompok tani Koko Naibate menggunakan tenaga kerja dalam keluarga yang berjumlah 45 orang dengan rerata curahan tenaga kerja sebesar 7,71 HKO.

- Penyiangan

Penyiangan yang dilakukan di Kelompok tani Koko Naibate yaitu membersihkan rumput menggunakan tajak. Penyiangan dilakukan setelah tanaman berumur \pm 2 minggu sesudah penanaman. Kelompok tani Koko Naibate menggunakan tenaga kerja dalam keluarga yang berjumlah 33 orang dengan rerata curahan tenaga kerja sebesar 10,57 HKO

- Penyiraman

Penyiraman yang dilakukan di kelompok tani Koko Naibate dilakukan pada pagi hari atau sore hari dengan menggunakan ember. Penyiraman dilakukan secara merata, agar menciptakan kondisi lahan yang tetap lembab dengan tujuan agar mempermudah akar tanaman untuk tumbuh dan berkembang dengan baik. Penggunaan airnya diperoleh dari anak sungai. Kelompok tani Koko Naibate menggunakan tenaga kerja dalam keluarga yang berjumlah 35 orang dengan rerata curahan tenaga kerja sebesar 5,77 HKO.

\section{f. Panen dan Pasca Panen}

Tanaman terong ungu dipanen pada usia 70 - 80 hari setelah masa tanam. Masa produktif tanaman yaitu 1 tahun, rata-rata terong ungu di kelompok tani Koko Naibate dapat dipanen tiga hari sekali. Pemanenan di Kelompok Tani Koko Naibate biasanya dilakukan secara manual yaitu dipetik menggunakan tangan. Sesudah dipetik terong ungu disimpan pada tempat yang kering dan sejuk. Sebagian besar terong ungu dijual untuk memenuhi kebutuhan keluarga, biaya anak sekolah, urusan sosial dan ada yang di konsumsi. Kelompok tani Koko Naibate menggunakan tenaga kerja dalam keluarga yang berjumlah 55 orang dengan rerata curahan tenaga kerja sebesar $12,16 \mathrm{HKO}$

\subsection{Faktor-Faktor yang Mempengaruhi Produksi Usahatani Terong} Ungu

Analisis yang digunakan pada penelitian ini adalah analisis regresi berganda dalam bentuk logaritma dengan fungsi produksi Cobb-Douglas. Hasil analisis ditampilkan pada Tabel 1.

Tabel 1. Analisis Regresi Berganda

\begin{tabular}{cccccc}
\hline \multirow{2}{*}{ Model } & \multicolumn{2}{c}{$\begin{array}{c}\text { Unstandardized } \\
\text { Coefficients }\end{array}$} & $\begin{array}{c}\text { Standardized } \\
\text { Coefficients }\end{array}$ & \multirow{2}{*}{ Thitung } & Sig. \\
\cline { 2 - 4 } & $\mathrm{B}$ & Std. Error & Beta & & \\
\hline (Constant) & 3,771 & 2,552 & & 1,478 & 0,157
\end{tabular}

\begin{tabular}{lccccc}
$\mathrm{X}_{1}$ & 1,095 & 2,390 & 0,458 & 2,223 & 0,652 \\
$\mathrm{X}_{2}$ & 0,578 & 0,329 & 10,591 & 1,759 & 0,746 \\
$\mathrm{X}_{3}$ & 0,041 & 0,106 & 0,092 & 0,386 & 0,704 \\
$\mathrm{X}_{4}$ & 0,041 & 0,048 & 0,186 & 0,859 & 0,402 \\
$\mathrm{X}_{5}$ & $-0,022$ & 0,057 & $-0,079$ & $-0,394$ & 0,698 \\
$\mathrm{X}_{6}$ & 0,015 & 0,046 & 0,068 & 0,332 & 0,744 \\
\hline
\end{tabular}

Hasil analisis data diperoleh persamaan regresi merupakan nilai koefisien dari setiap variabel bebas dan persamaannya adalah $\mathrm{Y}=\mathrm{Ln} 1,478$ $+2,223 \mathrm{X}_{1} \mathrm{Ln}+1,759 \mathrm{X}_{2} \mathrm{Ln}+0,386 \mathrm{X}_{3} \mathrm{Ln}+0,859 \mathrm{X}_{4}-0,394 \mathrm{X}_{5} \mathrm{Ln}+$ $0,332 \mathrm{X}_{6}$ Ln. Uji kelayakan model analisis Cobb-Douglass dalam menjelaskan produksi terong ungu diketahui dari uji $\mathrm{F}$, Koefisien Determinasi $\left(\mathrm{R}^{2}\right)$, dan uji t.

Uji F dilakukan untuk mengetahui secara bersama faktor-faktor yang mempengaruhi produksi terong ungu dan variabel bebas terdiri dari luas lahan $\left(\mathrm{X}_{1}\right)$, benih $\left(\mathrm{X}_{2}\right)$, tenaga kerja $\left(\mathrm{X}_{3}\right)$, pengalaman berusahatani $\left(\mathrm{X}_{4}\right)$, pendidikan $\left(\mathrm{X}_{5}\right)$, dan tanggungan keluarga $\left(\mathrm{X}_{6}\right)$, sedangkan variabel terikat yaitu produksi terong ungu (Y) dengan taraf kepercayaan $\alpha=5 \%(0,05)$.

\begin{tabular}{lccccc}
\multicolumn{1}{c}{ Tabel 2. Anova Regresi } & & & & \\
\hline \multicolumn{1}{c}{ Model } & $\begin{array}{c}\text { Sum of } \\
\text { Squares }\end{array}$ & df & $\begin{array}{c}\text { Mean } \\
\text { Square }\end{array}$ & F hitung & Sig. \\
\hline Regression & 0,037 & 6 & 0,006 & 2.765 & 0,044 \\
Residual & 0,040 & 18 & 0,002 & & \\
\hline Total & 0,076 & 24 & & &
\end{tabular}

Berdasarkan Tabel 2. dapat dijelaskan bahwa nilai signifikansi 0,044 dan lebih kecil dari $0,05(\alpha 5 \%)$ sehingga dapat dikatakan bahwa variabel bebas yang meliputi luas lahan $\left(\mathrm{X}_{1}\right)$ benih $\left(\mathrm{X}_{2}\right)$, tenaga kerja $\left(\mathrm{X}_{3}\right)$, pengalaman usahatani $\left(\mathrm{X}_{4}\right)$, pendidikan $\left(\mathrm{X}_{5}\right)$, tanggungan keluarga $\left(\mathrm{X}_{6}\right)$ secara bersama-sama memiliki pengaruh nyata terhadap produksi terong ungu.

Besarnya pengaruh variabel bebas terhadap variabel terikat dapat dilihat dari nilai $\mathrm{R}^{2}$ pada Tabel 3. Koefisien determinasi $\left(\mathrm{R}^{2}\right)$ dalam model memiliki nilai 0,480 yang dimana kontribusi variabel bebas yang terdiri dari luas lahan $\left(\mathrm{X}_{1}\right)$, benih $\left(\mathrm{X}_{2}\right)$, tenaga kerja $\left(\mathrm{X}_{3}\right)$, pengalaman usahatani $\left(\mathrm{X}_{4}\right)$ pendidikan $\left(\mathrm{X}_{5}\right)$, tanggungan keluarga $\left(\mathrm{X}_{6}\right)$, memiliki pengaruh sebesar $48 \%$ terhadap peningkatan maupun penurunan produksi sedangkan sisanya sebesar 52\% dijelaskan oleh faktor selain faktor yang diteliti.

Tabel 3. Koefisien Determinasi $\left(\mathrm{R}^{2}\right)$

\begin{tabular}{ccccc}
\hline Model & $\mathrm{R}$ & $\mathrm{R}$ Square & Adjusted R Square & Std. Error of the Estimate \\
\hline 1 & 0,693 & 0,480 & 0,306 & 0,04696 \\
\hline
\end{tabular}

Uji t dilakukan untuk mengetahui pengaruh variabel bebas yang diteliti secara individual terhadap produksi terong ungu di kelompok tani Koko Naibate Desa Manunain A. Pengaruh secara parsial dari faktor luas lahan $\left(\mathrm{X}_{1}\right)$, benih $\left(\mathrm{X}_{2}\right)$, tenaga kerja $\left(\mathrm{X}_{3}\right)$, pengalaman usahatani $\left(\mathrm{X}_{4}\right)$, pendidikan $\left(\mathrm{X}_{5}\right)$, tanggungan keluarga $\left(\mathrm{X}_{6}\right)$, terhadap produksi terong ungu diuraikan sebagai berikut:

a. Luas Lahan $\left(\mathrm{X}_{1}\right)$

Luas lahan dalam penelitian ini adalah besarnya luas lahan yang digunakan oleh kelompok tani dalam berusahatani terong ungu. Nilai signifikansi variabel luas lahan bernilai 0,652 dan lebih besar dari $0,05(\alpha$ $5 \%$ ) sehingga dapat dikatakan bahwa luas lahan tidak berpengaruh terhadap produksi terong ungu di kelompok tani Koko Naibate.

b. Benih $\left(\mathrm{X}_{2}\right)$

Benih dalam penelitian ini adalah besarnya bibit yang digunakan oleh kelompok tani dalam satu kali tanam. Nilai signifikansi variabel benih bernilai 0,746 dan lebih besar dari $0,05(\alpha$ 5\%) sehingga dapat dikatakan bahwa benih tidak berpengaruh terhadap produksi terong ungu di kelompok tani Koko Naibate.

c. Tenaga Kerja $\left(\mathrm{X}_{3}\right)$

Tenaga kerja dalam penelitian ini dihitung dalam HKO dan tenaga kerja berasal dari dalam keluarga responden itu sendiri. Nilai signifikansi variabel tenaga kerja bernilai 0,704 dan lebih besar dari 0,05 ( $\alpha$ 5\%) sehingga dapat dikatakan bahwa tenaga kerja tidak berpengaruh terhadap produksi terong ungu di kelompok tani Koko Naibate.

d. Pengalaman Usahatani $\left(\mathrm{X}_{4}\right)$

Pengalaman yang dimaksudkan dalam penelitian ini adalah pengalaman responden dalam berusahatani terong ungu. Nilai signifikansi variabel pengalaman usahatani bernilai 0,402 dan lebih besar dari 0,05 ( $\alpha 5 \%)$ sehingga dapat dikatakan bahwa pengalaman usahatani tidak berpengaruh terhadap produksi terong ungu di kelompok tani Koko Naibate.

e. Pendidikan $\left(\mathrm{X}_{5}\right)$

Pendidikan yang dimaksudkan dalam penelitian ini adalah pendidikan yang ditempuh oleh kelompok tani mulai dari jenjang SD - SMA yang disertai dengan mengikuti penyuluhan dan pelatihan. Nilai signifikansi variabel pendidikan bernilai 0,698 dan lebih besar dari 0,05 ( $\alpha$ 5\%) sehingga 
dapat dikatakan bahwa pendidikan tidak berpengaruh terhadap produksi terong ungu di kelompok tani Koko Naibate.

f. Tanggungan Keluarga $\left(\mathrm{X}_{6}\right)$

Tanggungan keluarga yang dimaksudkan dalam penelitian ini adalah jumlah anggota keluarga yang menjadi tanggung jawab kepala keluarga yang berkisar dari $3-8$ orang. Nilai signifikansi variabel tanggungan keluarga bernilai 0,744 dan lebih besar dari $0,05(\alpha$ 5\%) sehingga dapat dikatakan bahwa tanggungan keluarga tidak berpengaruh terhadap produksi terong ungu di kelompok tani Koko Naibate.

Secara umum hasil penelitian memberikan gambaran bahwa variabel luas lahan, benih, tenaga kerja, pengalaman usahatani, pendidikan, dan tanggungan keluarga secara simultan berpengaruh nyata terhadap produksi terong ungu yang dibuktikan dengan nilai signifikansi anova regresi $(0,044)$ yang lebih kecil dari $0,05(\alpha 5 \%)$, tetapi kontribusi variabel-variabel tersebut dalam menjelaskan produksi hanya sebesar $48 \%$. Lebih lanjut variabel luas lahan, benih, tenaga kerja, pengalaman usahatani, pendidikan, dan tanggungan keluarga secara parsial tidak berpengaruh nyata terhadap produksi. Fakta bahwa usahatani terong ungu dilaksanakan dalam satu kelompok tani yang sama menyebabkan input yang diberikan dalam usahatani relatif seragam atau homogen antara responden, sebaliknya produksi yang diperoleh cukup bervariasi. Berdasarkan koefisien determinasi, sebesar $52 \%$ variasi produksi justru dijelaskan oleh variabel selain luas lahan, benih, tenaga kerja, pengalaman usahatani, pendidikan, dan tanggungan keluarga. Berdasarkan pengamatan visual di lokasi penelitian, terdapat variasi struktur dan tekstur tanah pada lahan petani responden. Diduga bahwa hal ini menyebabkan respon pertumbuhan dan hasil tanaman terhadap pemberian pupuk yang diberikan dalam bentuk cair bervariasi sehingga menyebabkan adanya perbedaan produksi yang diperoleh antara responden yang telah memberikan input yang relatif sama.

\section{Simpulan}

Usahatani terong ungu di kelompok tani Koko Naibate Desa Manunain A dilaksanakan dengan tahapan 1) persiapan dan pengolahan lahan; 2) pemilihan benih; 3) persemaian; 4) penanaman; 5) pemeliharaan; dan 6) panen dan pasca panen. Secara simultan variabel luas lahan, benih, tenaga kerja, pengalaman usahatani, pendidikan, dan tanggungan keluarga berpengaruh terhadap produksi terong ungu tetapi hanya $48 \%$ produksi yang dijelaskan oleh variabel-variabel tersebut. Secara parsial variabel luas lahan, benih, tenaga kerja, pengalaman usahatani, pendidikan, dan tanggungan keluarga tidak berpengaruh nyata terhadap produksi usahatani terong ungu di kelompok tani Koko Naibate Desa Manunain A.

\section{Pustaka}

Murdiantoro, B. 2011. Faktor-Faktor yang Mempengaruhi Produksi Padi di Desa Pulorejo Kecamatan Winong Kabupaten Pati. Universitas Negeri Semarang.

Phahlevi, R. 2013. Faktor-faktor yang mempengaruhi pendapatan petani padi sawah di Kota Padang Panjang. Jurnal Ekonomi Pembangunan, 1(02): $1-22$

Rukmana, R. 2007. Bertanam Terung. Yogyakarta: Kanisius.

Santoso, S. 2008. Panduan Lengkap Menguasai Spss 16. Jakarta: Elex Media Komputindo.

Soekartawi 1990. Teori Ekonomi Produksi dengan Pokok Bahasan Analisis Fungsi Cobb-Douglas. Depok: Rajawali Pers.

Sugiyono, 2006. Metode Penelitian Kuantitatif, Kualitatif dan $R \& D$. Bandung: Alfabeta.

Tou, M.D. 2017. Faktor-Faktor yang Mempengaruhi Produksi Usahatani Padi Sawah di Desa Angkaes Kecamatan Weliman Kabupaten Malaka. AGRIMOR,2(03):41-43. 